\title{
(6) OPEN ACCESS \\ A study of pyrazines in cigarettes and how additives might be used to enhance tobacco addiction
}

\author{
Hillel R Alpert, Israel T Agaku, Gregory N Connolly
}

\author{
Correspondence to \\ Dr Hillel R Alpert \\ halpert@hsph.harvard.edu \\ Received 30 July 2014 \\ Revised 31 March 2015 \\ Accepted 1 April 2015 \\ Published Online First \\ 10 June 2015
}

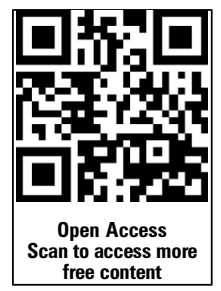

CrossMark

To cite: Alpert HR, Agaku IT, Connolly GN. Tob Control 2016;25:444-450.

\section{ABSTRACT}

Background Nicotine is known as the drug that is responsible for the addicted behaviour of tobacco users, but it has poor reinforcing effects when administered alone. Tobacco product design features enhance abuse liability by (A) optimising the dynamic delivery of nicotine to central nervous system receptors, and affecting smokers' withdrawal symptoms, mood and behaviour; and (B) effecting conditioned learning, through sensory cues, including aroma, touch and visual stimulation, to create perceptions of pending nicotine reward. This study examines the use of additives called 'pyrazines', which may enhance abuse potential, their introduction in 'lights' and subsequently in the highly market successful Marlboro Lights (Gold) cigarettes and eventually many major brands.

Methods We conducted internal tobacco industry research using online databases in conjunction with published scientific literature research, based on an iterative feedback process.

Results Tobacco manufacturers developed the use of a range of compounds, including pyrazines, in order to enhance 'light' cigarette products' acceptance and sales. Pyrazines with chemosensory and pharmacological effects were incorporated in the first 'full-flavour, lowtar' product achieving high market success. Such additives may enhance dependence by helping to optimise nicotine delivery and dosing and through cueing and learned behaviour.

Conclusions Cigarette additives and ingredients with chemosensory effects that promote addiction by acting synergistically with nicotine, increasing product appeal, easing smoking initiation, discouraging cessation or promoting relapse should be regulated by the US Food and Drug Administration. Current models of tobacco abuse liability could be revised to include more explicit roles with regard to non-nicotine constituents that enhance abuse potential.

\section{INTRODUCTION}

Tobacco dependence is understood to be a complex process that is primarily caused by the pharmacological effects of nicotine which activate nicotinic acetylcholine receptors in the brain leading to release of the neurotransmitter dopamine into the mesolimbic area, corpus striatum and frontal cortex. $^{1-6}$ Dopamine release induces rewards, including pleasure, arousal, mental acuity and modulation of mood. ${ }^{1}$ Since the 1980 s, nicotine is believed to play a central role in biological reinforcement, tolerance and physical dependence, and withdrawal symptoms on discontinuation of intake. $^{7}$ However, substantial evidence exists to suggest that nicotine's reinforcing effects alone are not sufficient to account for the intense addictive properties of tobacco smoking and the high relapse rates among smokers after quitting even when provided nicotine in forms other than tobacco. ${ }^{8-16}$ Further evidence that tobacco dependence entails more than addiction to nicotine includes the drug's limited ability to induce self-administration in animals $;{ }^{17} 18$ lack of positive mood effects of pure nicotine in abstinent smokers; ${ }^{19-21}$ lack of findings that nicotine in any other form than tobacco was preferred to placebo in normal smokers; ${ }^{22} 23$ de-nicotinised cigarettes were as effective as regular cigarettes, and more than nicotine in any other delivery mode, in relieving withdrawal and craving; ${ }^{24-27}$ and essential role of non-nicotine factors in cigarette addiction. ${ }^{24} 28$

The release of tobacco industry documents in the 1990s and investigation by the US Food and Drug Administration (FDA) brought to light tobacco manufacturers' research and development of the use of additives and ingredients besides nicotine which led to the increased appeal, attractiveness and addictiveness of products. ${ }^{3-5}{ }^{29}$ Independent scientific evidence has demonstrated that conditioned cues produced by tobacco non-nicotine ingredients and smoke constituents are instrumental in maintaining

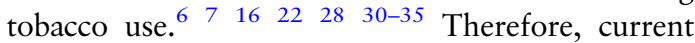
models of tobacco product abuse potential recognise nicotine as the primary drug of addiction, and that non-nicotine tobacco constituents and sensory stimuli from packaging and environmental cues also contribute to tobacco dependence. ${ }^{36}$

Two major determinants of abuse potential are (A) dynamic pharmacokinetics of nicotine delivery and (B) learned behaviour effects triggered by sensory cues associated with use. ${ }^{36} 37$ A smoker may feel the need to puff in order to attain threshold doses of nicotine and elicit the hedonic effects attributable to dopaminergic system reward pathways. ${ }^{38}$ Nicotine delivery and its perception may be related to ease of the drug's administration and the 'impact' of tobacco smoke on posterior pharynx nociceptors, which is proposed to occur primarily by free nicotine. ${ }^{39} 40$ Puff volume, speed of delivery, lung deposition, frequency of dosing, arterial absorption and other parameters affect the efficiency of nicotine delivery. ${ }^{41}$

Tobacco manufacturers modified the design of products by directly adding constituents to cigarettes that stimulate gustatory, tactile and olfactory nerve receptors and create chemosensory effects that could enhance elasticity in nicotine dosing as well as strengthen sensory cueing to optimise the 'pleasure' in smoking. ${ }^{38}{ }^{42-51}$ Pyrazines, a class of chemosensory agents, comprise 15 of the 599 compounds on the list of cigarette ingredients 
provided by manufacturers to the US Department of Health and Human Services in $1994,{ }^{52} 8$ of the compounds on the list of additive ingredients provided by manufacturers to the FDA in $2011^{53}$ and 10 of the compounds presently listed on cigarette manufacturers' website as cigarette ingredients" ${ }^{54-56}$ (box 1). The present study explores tobacco industry research that first identified pyrazines in tobacco smoke and was followed by the introduction of pyrazines in 'light' cigarettes and subsequent incorporation into Marlboro Lights and eventually in many other cigarette brands. It further examines their possible role in abuse potential.

\section{METHODS}

More than 7000000 tobacco industry documents have been disclosed by the major tobacco companies during litigation processes and made public as a result of the Minnesota Tobacco Trial and the Master Settlement Agreement of 1998. ${ }^{57} 58$ We searched online internal tobacco industry document databases housed at Tobacco Documents Online (http:// www.tobaccodocuments.org), the British American Tobacco Document Archive (http:/bat.library.ucsf.edu) and the Legacy Tobacco Documents Library (http://legacy.library.ucsf.edu). Standard methods used for document analysis have been described in detail elsewhere. ${ }^{59}{ }^{60}$ Document identification was performed using an index-based word search of titles, authors, recipients and other document characteristics (such as date, document type, original file location), as well as keywords and abstracts. Whenever available, full-text optical character recognition was also used.

We used a snowball sampling method to first search the databases using an initial set of key words (eg, pyrazines, flavorant, flavoring, flavor, chemosensory, sensory, low-tar, stimulation, attributes, perception, effects, taste, smoothness and product development) and relevant combinations of these terms, and to

Box 1 Pyrazine compounds in manufacturers' reports of cigarette ingredients

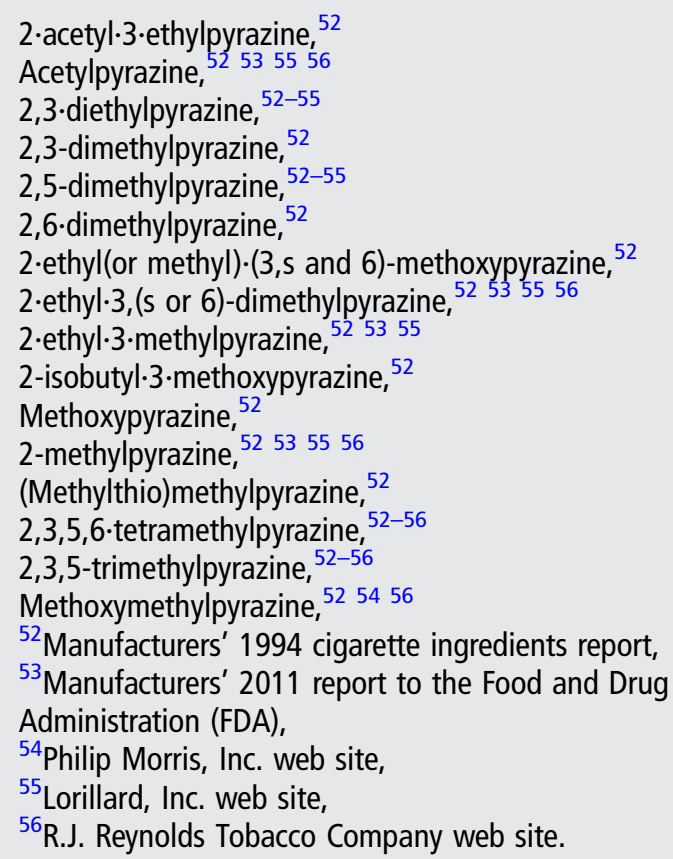

generate further search terms from the documents identified. Relevant documents were abstracted and indexed. The resulting document set was surveyed for recurring authors, keywords, codes or project names that would suggest further avenues for retrieval.

A number of unique difficulties associated with the use of internal industry documents as a source of scientific information must be considered. Industry research was not generally subjected to careful peer review, and details regarding the experimental methods used and the resulting quality of the data are often unavailable, making it difficult to assess the reliability of the science. In addition, the available documents do not always represent the totality of the internal research that was conducted on a particular topic-as indicated by the existence of many partial reports and memos. Finally, within each given company, the documents are authored by numerous different researchers from a range of departments over tens of years, and so findings are sometimes inconsistent and occasionally even contradictory. Comparisons of the documents reveal real company-to-company differences in approach to the engineering of tobacco product design, a finding that must be taken into account. For these reasons and to inform the findings in internal industry documents, we conducted this research in conjunction with a systematic review of evidence from the current scientific literature indexed in databases including PubMed (http://www.pubmed. gov) and Web of Science (http://thomsonreuters.com/web-ofscience) using the same search strategies.

\section{RESULTS}

\section{Introduction of pyrazines in cigarettes}

The first US Surgeon General Report in 1964, which greatly increased concerns about the dangers of smoking, and the decline in cigarette sales beginning for the first time since World War II gave a major impetus to the tobacco industry's efforts to increase product appeal. ${ }^{61}$ Tobacco manufacturers introduced new cigarette brands in response to these concerns, using filter ventilation, which lowered tar and nicotine yields or altered ratios measured under a standardised machine-based testing protocol. ${ }^{38}$ The 'low-tar' cigarettes were found to have diminished taste, aroma and flavour and a weaker impact on receptors in the throat. ${ }^{62}{ }^{63}$ Facing a decrease in smoking and continuing $2 \%$ annual decline in cigarette sales, Philip Morris (PM) endeavoured to develop cigarettes with even lower tar yields, yet with taste and flavour that would satisfy smokers' 'palates and needs. ${ }^{62}$

PM achieved a major breakthrough in this area by developing a 'full-flavour, low-tar product', marketed under the MERIT brand, which was the first 'light' cigarette. ${ }^{62}$ The company accomplished this by first selecting out components of the volatile fraction of the particulate phase that contributed the greatest odour intensity from among the multitudes of aromatic chemicals and substances in tobacco smoke. ${ }^{62}$ The gas chromatographic fractions of approximately 100 distinctive tobacco smoke flavourants were selected on the basis of high odour intensity as perceived by human participants using vapour dilution olfactometry. ${ }^{62}$ The molecular structures of these compounds were then tentatively identified by high resolution mass spectrometry and by comparing the 'cracking', a term used by PM for fragmentation patterns, with known reference spectra. PM then incorporated the flavourants of highest intensity into the variety of compounds to be added to the reconstituted tobacco sheet. The reformulated cigarette flavour systems provided the taste, flavour and aroma qualities of the low-tar delivery cigarettes. ${ }^{62}$ Finally, the company used panels of trained 
flavour experts to evaluate the smoke flavour of prototypes. PM's research and development resulted in a cigarette yielding less than $9 \mathrm{mg}$ tar with a smoke flavour of much higher tar yielding products. ${ }^{62}$

An extensive consumer testing programme of the new MERIT product was conducted, including blind interviews with nearly 3000 smoker panellists. ${ }^{62} 64$ The majority of consumer participants reported that the new MERIT was equal or superior in taste to brands that delivered 60\% more tar. Advertisements touted the product's 'enriched flavor' and described, "After twelve years of intensive research, Philip Morris scientists isolated certain key ingredients in smoke that deliver taste way out of proportion to tar." 65 (figure 1). This brand went on to capture a significant share of the low-tar cigarette market following its national launch in $1976 .^{62}$

PM called the new flavour formulation 'Super Juice', which contained 2,6-dimethyl pyrazine, tetramethyl pyrazine and trimethyl pyrazine as well as acetic acid, cyclotene, maltol, isobutyric acid and 1-methyl indole. ${ }^{66}$ Reverse engineering and research by British American Tobacco of PM products, MERIT, MERIT Menthol, Marlboro and Marlboro Lights identified at least six pyrazines: 2-methylpyrazine, methylethylpyrazine, dimethylethylpyrazine, 2,3-dimethylpyrazine, 2,6-dimethylpyrazine, trimethylpyrazine and tetramethylpyrazine, and found that pyrazines contribute to the burley flavour, which is a common characteristic of many PM brands (isomers noted only where referenced in document). ${ }^{67}$ In the USA in the late 1970s, 'Super Juice'-like compounds were added to Marlboro Lights, which is now called 'Marlboro Gold'. Ingredients also included essential oils, inorganic acids and other constituents, added to a reconstituted tobacco sheet with diammonium phosphate, which appears to have allowed better control of constituent release. ${ }^{68}$ Marlboro Lights have since become the leading selling cigarette brand.

\section{Pyrazine flavour profiles}

Pyrazines are heterocyclic aromatic organic compounds with the underlying chemical formula $\mathrm{C}_{4} \mathrm{H}_{4} \mathrm{~N}_{2}$. They are formed under pyrolytic conditions (temperatures $\geq 100^{\circ} \mathrm{C}$ ) via the Maillard Browning reaction between amines and carbonyl compounds (generally sugars) ${ }^{69} 70$ (figure 2), which occurs during the curing of tobacco leaf and during the smoking process. ${ }^{71} 72$ Numerous pyrazine compounds have been detected in foods, which arise from the common practice of heating and Maillard
Figure 1 Advertisement for new 'Enriched Flavor' MERIT cigarettes (1976).

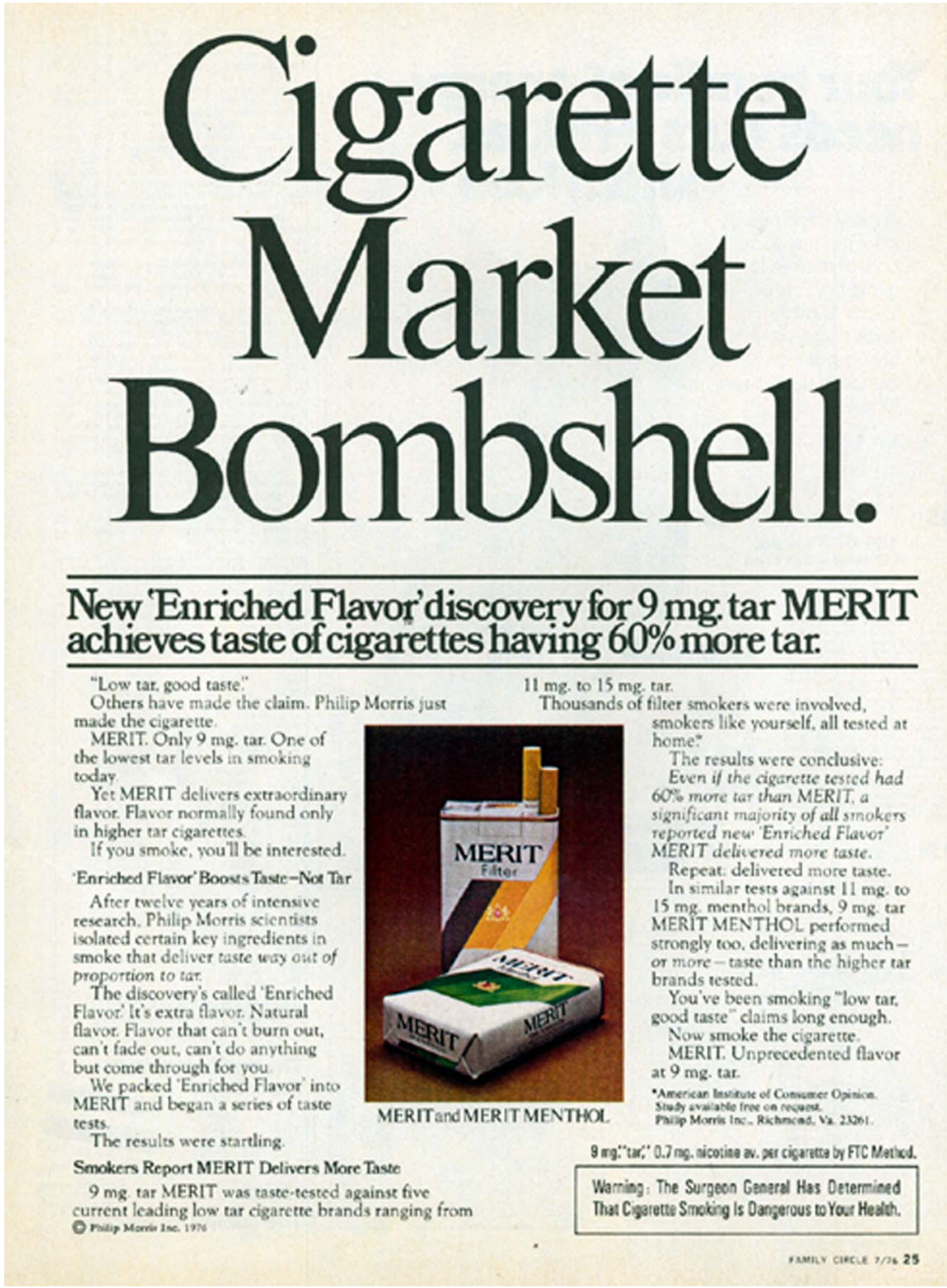


Figure 2 Graphic representation of the Maillard Browning reaction in the formation of pyrazines.

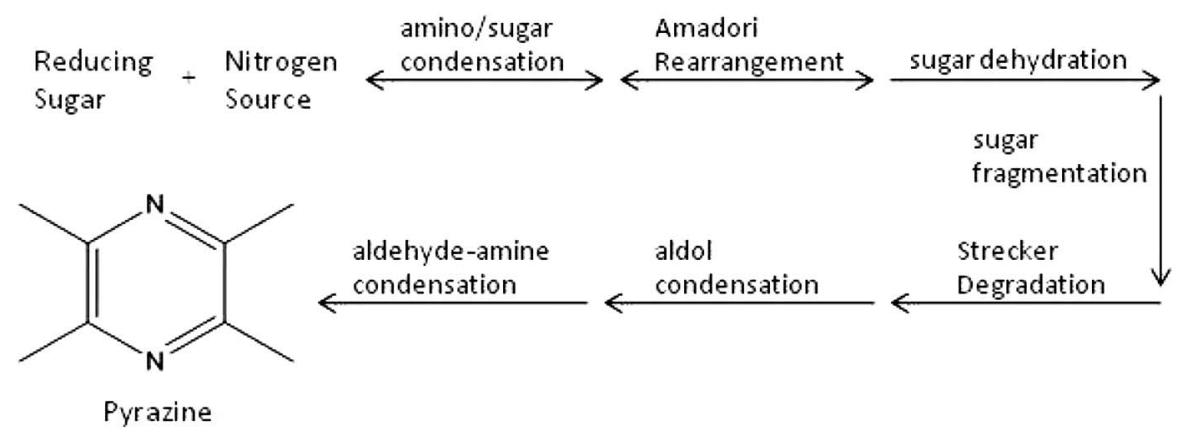

Pyrazines are yielded under pyrolytic conditions, mostly via the Maillard decomposition of

Amadori compounds at temperatures $\geq 100^{\circ} \mathrm{C}$. Shown is the tetramethyl version.
Browning reaction of sugars with protein and ammonia, providing a distinctive flavour. Other pyrazine compounds have been synthesised and promoted as flavouring agents because of their unique organoleptic properties and flavour and aroma profiles. $^{73-77}$ Pyrazines are 1 of 18 chemical classes of flavouring materials used in combustible tobacco products as described by Leffingwell et al. ${ }^{78}$ They have been said to be among the most important compounds characterising the aroma and flavour of tobacco and tobacco smoke, contributing the 'brown notes' in general, and at least in some cases the cocoa, nutty or popcorntype flavour notes. ${ }^{79}$

\section{Chemosensory effects}

Pyrazines are known to act on chemoreceptors, sensory receptors that transduce chemical signals into action potentials. ${ }^{80}$ In addition to conveying the classical senses of taste and smell in humans, the mouth, nose and airways also contain chemosensory nerve endings of the trigeminal nerve. ${ }^{81}$ These can be activated by physical stimuli as well as by a large array of chemical agents, leading to sensations such as burning, cooling and tingling, and contributing to flavour even in the absence of an olfactory percept. ${ }^{82}$ Chemosensory effects of some other additives to cigarettes have been described, including essential oils (eg, menthol) ${ }^{83}$ and organic acids (eg, levulinic acid). ${ }^{84}$

A report by the Tobacco Product Scientific Advisory Committee to the FDA described menthol's actions on transient receptor potential (TRP) channels, in particular TRPM8, which produce cooling and analgesia at low doses, irritation and pain at high doses, and desensitisation of the receptors with prolonged stimulation. ${ }^{85}$ The report described how the addition of menthol in cigarettes creates perceptions of smoothness at low levels and analgesia at high levels and reduces the discomfort of smoking in long-term users. Results of population studies cited in the report showed youth being more likely to initiate smoking with a low menthol brand (eg, Newport), and older adults being less likely with a high menthol brand (eg, Kool). ${ }^{85}$ An earlier review of internal tobacco industry documents reported the addition of levulinic acid to cigarettes to increase nicotine yields while enhancing perceptions of smoothness and mildness. $^{8486}$

Important chemosensory effects of pyrazines identified by the industry include smoothing, which may enhance the ease of inhalation and nicotine deposition by reducing the harshness and irritating effects of nicotine and other tobacco smoke constituents in the airways. ${ }^{87}$ PM's internal documents of 1990 pertaining to the company's chemical senses research programme describe how a "chain of events from stimulation in the mouth, the throat and at the olfactory level leads to transmembrane electrical signals which are integrated in the brain." 88 According to these documents, diffusion and binding of constituents to receptors at sites of action, generation of action potentials, transmembrane signalling and integration of the diverse stimulus signals result in percepts (perceptions), which the company attempted to balance in order to promote high consumer acceptance and continued use as opposed to rejection of the product. ${ }^{89}$

\section{Pyrazines and learned behaviour}

Pyrazine stimulation of olfactory receptors may enhance learned behaviour, either by acting alone or in combination with other sensory modality stimuli. ${ }^{90} 91$ Human responses to chemosensory and olfactory effects that are associated with emotionally significant experiences can become constitutional through neuroplastic changes in the olfactory pathways to the limbic system as well as other areas of the brain associated with hedonic perception. $^{92} 93$ Such events can reinforce smoking through associative learning and become cues for increased hedonic valence of stimuli ${ }^{94}$ and motivate increased desire or wanting, or even unrestrained consumption.

\section{DISCUSSION}

This is the first report to document the tobacco industry's incorporation of pyrazine compounds into cigarettes since the early 1970 s which appear to contribute to the products' appeal and abuse potential. Effects of pyrazines in cigarettes as described in industry documents reflect a range of processes by which such non-nicotine constituents might increase tobacco product abuse potential. ${ }^{84}$ Pyrazines may act in concert with nicotine either by chemosensory effects that reduce noxious sensations such as irritation in the upper ways and ease nicotine uptake and entry into the lung. They may also act by chemosensory effects that reinforce the learned behaviour of smoking, enhance elasticity and help optimise nicotine dosing to achieve a desired delivery to the brain and satisfy a smoker's need for the drug based on mood and circumstances. ${ }^{95}$ Several pyrazine derivatives have also been found to potentiate 5 -HT binding to receptors in the central nervous system, which results in enhanced dopamine release independently of nicotine. ${ }^{96-98}$ 
Chemosensory effects such as perceived smoothing and coolness (tactile) are associated with decreased aversion to smoking from the harshness and irritation of initial exposure to nicotine among novice smokers. ${ }^{99} 100$ Similar effects have been described for menthol. ${ }^{84}$ These effects might be a factor in smokers switching to 'low-tar' brands as an alternative to quitting smoking, going beyond the cognitive perception of reduced disease risk, to the emotive, physical perception that the smoke is 'smoother' and thus less harmful. Further, an RJR 1986 brand report describes the company's targeting of males 18-24 years of age by increasing the smoothness and masking the harshness and irritation of tobacco smoke. ${ }^{101}$ The observed effects of pyrazines on secondhand smoke (SHS) demonstrate that these compounds were also used to reduce the irritation from SHS among non-smokers. ${ }^{102}$ If non-smokers exposed to SHS perceive less risk due to lower irritation, without an actual reduction in their toxic constituents and effects, pyrazines might be classifiable as 'potentially hazardous constituents' under Section 904 of the Family Smoking and Tobacco Prevention Act of 2009 (FSPTCA).

Although independent research has been conducted on the effects on tobacco use of distal cueing from visual exposure to tobacco advertising and from social stimuli, little attention outside of tobacco manufacturers has previously been given to the more proximal cues that directly stimulate receptors of the head and neck. ${ }^{89}$ The sensory inputs of pyrazine flavour additives might also provide cues for reward-related learned behaviours and could play a critical role in the development, maintenance and relapse of tobacco dependence. They could increase the attractiveness of smoking, particularly among youth. ${ }^{103}$ Substantial evidence exists to suggest that flavour ingredients are used in cigarette 'starter' products, which increase cigarette experimentation and may help establish smoking behaviours that could lead to a lifetime of addiction. ${ }^{103}$

The FSPTCA explicitly bans the use of additives in cigarettes that are 'characterising flavours', which as defined by FDA food regulations are those that have taste or gustatory (eg, sweet, salt, sour, bitter) effects and are used in labelling, such as 'chocolate' flavoured cigarettes. However, a 'characterising' gustatory flavour may have relatively little significance if the major effect of an additive is on the olfactory and tactile receptors. British-American Tobacco concluded from research conducted that the prime sensorial experiences of smoking are associated with chemosensory flavour (odours, aroma) and irritation (tactile) sensations, whereas the gustatory qualities were found to be relatively less important for product attractiveness and appeal. ${ }^{104}$ Flavour ingredients such as cocoa, licorice or vanilla have remained present in major cigarettes brands since prior to the ban's implementation, ${ }^{54}$ which raises questions about the efficacy of the ban on the use of flavour ingredients and their consequential effects. When defining 'characterising' flavours for combusted tobacco products, the FDA Center for Tobacco Products should consider the distinction between flavours whose effects are primarily gustatory and flavours with olfactory or tactile effects.

Experimental use of electronic nicotine delivery systems (ENDS) has been rapidly increasing among teens. ${ }^{105-108}$ Not surprisingly, the liquid flavour fluid formulations of ENDS include pyrazine additives such as 2,3,5,6-tetramethyl-pyrazine (0.9-1.5\%), 2,3,5-trimethylpyrazine $(0.3-4.5 \%)$ and acetylpyrazine $(0.4-1.6 \%),{ }^{109}$ which also appear on the aforementioned lists of cigarette additives. Taken together, pyrazines appear to increase product appeal and make it easier for non-smokers to initiate smoking, more difficult for current smokers to quit, much easier for former smokers to relapse into smoking, and may mask the risks of both active and passive smoking.

The present findings should be interpreted in the context of the unique challenges of tobacco document research and known limitations with respect to documents availability. Access to the most recent industry documents is limited; use of terminology, practices and methods varies between companies and over time; and industry documents pertaining to pyrazines since the 1990s are largely unknown. Research conducted by industry is for business and commercial purposes, has not been peer reviewed and cannot be considered to be conclusive, absent independent confirmation. Therefore, a larger body of evidence should be considered with respect to the implications of these findings for public health and policy.

Future studies could focus on understanding the pivotal roles of pyrazines, their derivatives and other 'flavour' additives that stimulate neural receptors in neurobiological pathways, and actions in areas of the brain that affect abuse liability. Research could be conducted to examine the physiological and pharmacological actions of pyrazines and provide insight into the transduction mechanisms, receptor structure and chemical structure-activity relationships. Electrophysiological responses to chemosensory stimulants using radioactive labelled pyrazines and functional MRI and EEG could highlight specific areas of the brain stimulated by pyrazines.

The tobacco industry has long been interested in maximising the attractiveness, appeal, ease-of-use and low health-risk perceptions of tobacco products in a highly competitive and unregulated market in order to increase sales and market share. ${ }^{29} 36-38$ To that end, manufacturers have researched and designed cigarettes with constituents that act independently of as well as synergistically with nicotine and may enhance abuse potential. The findings that are provided by these and other reports may help enable regulators such as the FDA, Health Canada, European Union and the WHO to develop standards to reverse these actions and reduce the addictiveness of tobacco products.

\section{What this paper adds}

- Nicotine is known as the drug that is responsible for the addicted behaviour of tobacco users, but it has been argued that non-nicotine factors are also essential to account for the intense addictive properties of tobacco smoking and high relapse rates among smokers after quitting.

- This study reveals how some tobacco manufacturers innovated with the use of pyrazines as additives. Pyrazines have been reported to have chemosensory and pharmacological properties and appear to be widely used now in cigarette brands.

- Pyrazines may help to optimise nicotine delivery and dosing, and promote addiction through cueing, learned behaviour and/or direct effects.

Disclaimer This research was conducted by the authors while at the Harvard School of Public Health. Dr Connolly is now Professor of Research at Northeastern University.

Contributors GNC had primary responsibility for the conception of the research. HRA, ITA and GNC contributed to the design of the research. HRA and ITA conducted the research and prepared drafts of the manuscript. GNC contributed to the editing of the manuscript drafts, and HRA prepared the final manuscript.

Funding This research was supported by the National Cancer Institute grant numbers 3R01 CA125224-03s1rev++ and 2R01 CA087477-09A2. 
Competing interests ITA initiated his work on the reported research while affiliated with the Center for Global Tobacco Control at Harvard School of Public Health. He is currently affiliated with the Centers for Disease Control and Prevention's Office on Smoking and Health.

Provenance and peer review Not commissioned; externally peer reviewed.

Open Access This is an Open Access article distributed in accordance with the Creative Commons Attribution Non Commercial (CC BY-NC 4.0) license, which permits others to distribute, remix, adapt, build upon this work non-commercially, and license their derivative works on different terms, provided the original work is properly cited and the use is non-commercial. See: http://creativecommons.org/ licenses/by-nc/4.0/

\section{REFERENCES}

1 Benowitz NL. Nicotine addiction. N Engl J Med 2010;362:2295-303.

2 Liu L, Zhao-Shea R, McIntosh JM, et al. Nicotine persistently activates ventral tegmental area dopaminergic neurons via nicotinic acetylcholine receptors containing $\alpha 4$ and $\alpha 6$ subunits. Mol Pharmacol 2012;81:541-8.

3 U.S. Department of Health and Human Services. How tobacco smoke causes disease: the biology and behavioral basis for smoking-attributable disease: a report of the Surgeon General. Atlanta, GA: U.S. Department of Health and Human Services, Centers for Disease Control and Prevention, National Center for Chronic Disease Prevention and Health Promotion, Office on Smoking and Health, 2010.

4 US. Department of Health and Human Services. The health consequences of smoking: 50 years of progress. A Report of the Surgeon General. Atlanta, GA: U.S. Department of Health and Human Services, Centers for Disease Control and Prevention, National Center for Chronic Disease Prevention and Health Promotion, Office on Smoking and Health, 2014. Printed with corrections, January 2014.

5 Food and Drug Administration. Regulations restricting the sale and distribution of cigarettes and smokeless tobacco products to protect children and adolescents; proposed rule analysis regarding FDA's jurisdiction over nicotine-containing cigarettes and smokeless tobacco products; notice. Fed Regist 1995;60:41314-792.

6 WHO Study Group on Tobacco Product Regulation. Report on the Scientific Basis of Tobacco Product Regulation: fourth report of a WHO study group. WHO Technical Report Series; No. 967. http://www.who.int/tobacco/publications/prod_ regulation/trs_967/en/index.html (accessed 2 Jan 2013).

7 U.S. Department of Health and Human Services. The health consequences of smoking: nicotine addiction. A report of the Surgeon General. Rockville, MD: Public Health Service, 1988.

8 Guillem K, Vouillac C, Azar MR, et al. Monoamine oxidase inhibition dramatically increases the motivation to self-administer nicotine in rats. J Neurosci 2005;25:8593-600.

9 Corrigall WA, Coen KM. Nicotine maintains robust self-administration in rats on a limited-access schedule. Psychopharmacology (Berl) 1989;99:473-8.

10 Donny EC, Caggiula AR, Knopf $S$, et al. Nicotine self-administration in rats. Psychopharmacology (Berl) 1995;122:390-4.

11 Rose JE, Corrigall WA. Nicotine self-administration in animals and humans: similarities and differences. Psychopharmacology (Berl) 1997;130:28-40.

12 Alpert HR, Connolly GN, Biener L. A prospective cohort study challenging the effectiveness of population-based medical intervention for smoking cessation. Tob Control 2013;22:32-7.

13 Pierce JP, Gilpin EA. Impact of over-the-counter sales on effectiveness of pharmaceutical aids for smoking cessation. JAMA 2002;288:1260-4.

14 Wakefield MA, Durkin S, Spittal MJ, et al. Impact of tobacco control policies and mass media campaigns on monthly adult smoking prevalence. Am J Public Health 2008;98:1442-50.

15 Walsh RA. Over-the-counter nicotine replacement therapy: a methodological review of the evidence supporting its effectiveness. Drug Alcohol Rev 2008;27:529-47.

16 Caggiula AR, Donny EC, Chaudri N, et al. Importance of nonpharmacological factors in nicotine self-administration. Physiol Behav 2002;77:683-7.

17 McDonald RV, Parker LA, Siegel S. Conditioned sucrose aversion produced by naloxone precipitated withdrawal form acutely administered morphine. Pharmacol Biochem Behav 1997;58:1003-8.

18 Dar R, Frenk H. Nicotine self-administration in animals: a reevaluation. Addict Res Theory 2002;10:545-79.

19 Perkins KA, Grobe JE, Weiss D, et al. Nicotine preference in smokers as a function of smoking abstinence. Pharmacol Biochem Behav 1996;55:257-63.

20 Hughes JR, Rose GL, Callas PW. Do former smokers respond to nicotine differently from never smokers? A pilot study. Nicotine Tob Res 2000;2:255-62.

21 West R, Hajek P, Foulds J, et al. A comparison of the abuse liability and dependence potential of nicotine patch, gum, spray and inhaler. Psychopharmacology (Berl) 2000;149:198-202.

22 Dar R, Frenk H. Do smokers self-administer pure nicotine? A review of the evidence. Psychopharmacology (Berl) 2004;173:18-26.
23 Dar R, Frenk H. Smokers do not self-administer nicotine other than in tobacco: a reply to Perkins (2004). Psychopharmacology (Berl) 2004;175:259-61.

24 Rose JE, Behm FM, Westman EC, et al. Dissociating nicotine and nonnicotine components of cigarette smoking. Pharmacol Biochem Behav 2000;67:71-81.

25 Buchhalter AR, Schrinel L, Eissenberg T. Withdrawal suppressing effects of a novel smoking system: comparison with own brand, not own brand, and de-nicotinized cigarettes. Nicotine Tob Res 2001;3:111-18.

26 Shahan TA, Bickel WK, Madden GJ, et al. Comparing the reinforcing efficacy of nicotine containing and denicotinized cigarettes: a behavioral economic analysis. Psychopharmacology (Berl) 1999;147:210-16.

27 Shahan TA, Bickel WK, Badger GJ, et al. Sensitivity of nicotine-containing and de-nicotinized cigarette consumption to alternative non-drug reinforcement: a behavioral economic analysis. Behav Pharmacol 2001;12:277-84.

28 Rose JE. Nicotine and nonnicotine factors in cigarette addiction. Psychopharmacology (Berl) 2006;184:274-85.

29 Oslo monograph: Advancing knowledge on regulating tobacco products. International Conference on Advancing Knowledge on Regulating Tobacco Products, 9-11 February 2000, Oslo, Norway.

30 Rose JE, Salley A, Behm FM, et al. Reinforcing effects of nicotine and non-nicotine components of cigarette smoke. Psychopharmacology (Berl) 2010;210:1-12.

31 Hurt RD, Robertson CR. Prying open the door to the tobacco industry's secrets about nicotine: the Minnesota Tobacco Trial. JAMA 1998;280:1173-81.

32 Slade J, Bero LA, Hanauer P, et al. Nicotine and addiction. The Brown and Williamson documents. JAMA 1995;274:225-33.

33 Hoffman AC, Evans SE. Abuse potential of non-nicotine tobacco smoke components: acetaldehyde, nornicotine, cotinine, and anabasine. Nicotine Tob Res 2013;15:622-32.

34 Goldberg SR, Spealman RD, Risner ME, et al. Control of behavior by intravenous nicotine injections in laboratory animals. Pharmacol Biochem Behav 1983;19:1011-20.

35 Henningfield JE, Goldberg SR. Nicotine as a reinforcer in human subjects and laboratory animals. Pharmacol Biochem Behav 1983;19:989-92.

36 Carter LP, Stitzer ML, Henningfield JE, et al. Abuse liability assessment of tobacco products including potential reduced exposure products. Cancer Epidemiol Biomarkers Prev 2009;18:3241-62.

37 Henningfield JE, Hatsukami DK, Zeller $\mathrm{M}$, et al. Conference on abuse liability and appeal of tobacco products: conclusions and recommendations. Drug Alcohol Depend 2011;116:1-7.

38 National Cancer Institute. Risks associated with smoking cigarettes with low machine-measured yields of tar and nicotine. Smoking and Tobacco Control Monograph No. 13. Bethesda, MD: U.S. Department of Health and Human Services, National Institute of Health, National Cancer Institute, NIH Pub. No. 02-5074, 2001.

39 Ferris Wayne G, Connolly GN, Henningfield JE. Brand differences of free-base nicotine delivery in cigarette smoke: the view of the tobacco industry documents. Tob Control 2006;15:189-98.

40 Schori TR. Free nicotine: its implications on smoke impact. 22 October, 1979. Bates Number 542001985/1996.

41 Benowitz NL. Clinical pharmacology of nicotine: implications for understanding, preventing, and treating tobacco addiction. Clin Pharmacol Ther 2008;83:531-41.

42 Megerdichian C, Rees VW, Wayne GF, et al. Internal tobacco industry research on olfactory and trigeminal nerve response. Nicotine Tob Res 2007;11:1119-29.

43 Collishaw N. Manipulation. The story of imperial tobacco and its cigarettes. Ottawa: Physicians for a Smoke-free Canada, 1999. http://www.smoke-free.ca/ pdf_1/manipulatione.pdf

44 National Cancer Institute. Smoking and tobacco control monograph 7. Bethesda, MD: U.S. Department of Health and Human Services, National Institutes of Health, National Cancer Institute, 1996. The FTC Cigarette Test Method for Determining Tar, Nicotine, and Carbon Monoxide Yields of U.S. Cigarettes. NIH Pub.No.96-4028.

45 Djordjevic MV, Stellman SD, Zang E. Doses of nicotine and lung carcinogens delivered to cigarette smokers. J Natl Cancer Inst 2000;92:106-11.

46 Wilkenfeld J, Henningfield J, Slade J, et al. It's time for a change: cigarette smokers deserve meaningful information about their cigarettes. J Natl Cancer Inst 2000;19:90-2.

47 Watson CH, Trommel JS, Ashley DL. Solid-phase microextraction-based approach to determine free-base nicotine in trapped mainstream cigarette smoke total particulate matter. J Agric Food Chem 2004;52:7240.

48 Pankow JF, Tavakoli AD, Luo W, et al. Percent free base nicotine in the tobacco smoke particulate matter of selected commercial and reference cigarettes. Chem Res Toxicol 2003;16:1014-18.

49 Henningfield JE, Benowitz NL, Connolly GN, et al. Reducing tobacco addiction through tobacco product regulation. Tob Control 2004;13:132-5.

50 Carpenter CM, Wayne GF, Connolly GN. The role of sensory perception in the development and targeting of tobacco products. Addiction 2007;102:136-47.

51 Wayne GF, Connolly GN, Henningfield JE. Assessing internal tobacco industry knowledge of the neurobiology of tobacco dependence. Nicotine Tob Res 2004;6:927-40. 
52 R.J. Reynolds Tobacco Company. Cigarette ingredients: a complete list and background. Winston-Salem, NC: R.J. Reynolds Tobacco Company, 1994. Bates number 511981022/1046.

53 Letter. U.S. Food and Drug Administration, Center for Tobacco Products. Freedom of Information Act Office to GN Connolly. November 12, 2011. RE: FOIA Requests under Section 904, Family Smoking Prevention and Tobacco Control Act.

54 Philip Morris USA. http://www.philipmorrisusa.com/en/cms/Products/cigarettes/ Ingredients/Ingredients_By_Brand/default.aspx (accessed 1 Apr 2014).

55 Lorillard, Inc. http://www.Iorillard.com/wp-content/uploads/2012/02/Lorillard_ IngredientList March-2012.pdf (accessed 12 Nov 2013).

56 R.J. Reynolds Tobacco Company. http://www.rjrt.com/ingredients.aspx (accessed 12 Nov 2013).

57 Hurt RD, Ebbert JO, Muggli ME, et al. Open doorway to truth: legacy of the Minnesota tobacco trial. Mayo Clin Proc 2009;84:446-56.

58 Master Settlement Agreement. (1998) http://www.naag.org/backpages/naag/ tobacco/msa/msa-pdf (accessed 18 Jun 2013).

59 Bero L. Implications of the tobacco industry documents for public health and policy. Annu Rev Public Health 2003;24:267-88.

60 Malone RE, Balbach ED. Tobacco industry documents: treasure trove or quagmire? Tob Control 2000;9:334-8.

61 U.S Department of Health, Education, and Welfare. Smoking and health: report of the Advisory Committee of the Surgeon General of the Public Health Service. Washington DC: US Government Printing Office, 1964.

62 Philip Morris. Breakthrough of the high taste, low tar cigarette: a case history of innovation. Philip Morris, Inc., 1980. Bates number. $/ 6216$.

63 Lin SS. Basic flavor investigation low tar/high flavor literature review special. Philip Morris, Inc., 1990. Bates number 2046741788/1830.

64 American Institute of Consumer Opinion. The consumer testing of Merit cigarettes. Philip Morris, Inc., 1976. Bates number 2015010659/0669.

65 Trinkets and Trash. http://www.trinketsandtrash.org/detail.php? artifactid=9771\&page=1. Accessed April 16, 2015.

66 Ikeda RM. Super juice constituents. Philip Morris, Inc., 1975. Bates number 1003720260.

67 Crellin RA. Alkylpyrazine levels in Philip Morris brands: report no RD 1509 restricted. British-American Tobacco Company Limited, 1977. Bates number 105467378-05467412.

68 Aulback P, Black R, Chakaborty B, et al. Brown \& Williamson. Root technology; a handbook for leaf blenders and product developers. 1991. Bates 682439026/ 9083.

69 Nursten EH. The Maillard reaction: chemistry, biochemistry, implications. UK: RSC Publishing, 2005.

70 Ashoor SH, Zent JB. Maillard browning of common amino acids and sugars. J Food Sci 1984;49:1206-7.

71 Philip Morris. Recent advances in tobacco science. Volume 7 tobacco leaf chemistry: its origin, understanding and current trends. Philip Morris, 1981. Bates number: 2060456904.

72 R. J. Reynolds Medicine Sir. Tobacco smoke reduces the delivery of mainstream total particulate matter and, of course, its component parts, "tar" and nicotine. RJ Reynolds, 1989. Bates number 509896141.

73 Leffingwell JC, Young HJ, Bernasek E. Tobacco flavoring for smoking products. Winston-Salem, NC: R.J. Reynolds Tobacco Company, 1972.

74 Maga JA, Sizer CE. Pyrazines in food. J Agric Food Chem 1973;21:22-30.

75 Kane FC; Alapharetta Aromatics. Pyrazines and other flavors; pyrazines-their properties, reported uses, and technical information. RJ Reynolds, 1980. Bates number $510245748 / 510245754$.

76 Maga JA, Sizer SE, Myhre DV. Pyrazines in foods. CRC Crit Rev Food Technol 1973;4:39-115.

77 Pandit R, Mercer JG, Overduin J, et al. Dietary factors affect food reward and motivation to eat. Obesity facts. Obes Facts 2012;5:221-42.

78 Leffingwell JC, Young HJ, Bernasek E. Tobacco flavoring for smoking products. Winston-Salem: R.J. Reynolds Tobacco Company, 1972.

79 Rodgman A, Perfetti TA. The chemical components of tobacco and tobacco smoke. 2nd edn. Boca-Raton: CRC Press, 2013.

80 Bargmann Cl. Chemosensation in C. elegans. Vol 25. WormBook, 2006:1-29.

81 Frasnelli J, Albrecht J, Bryant B, et al. Perception of specific trigeminal chemosensory agonists. Neuroscience 2011;189:377-83.
82 Laska M, Distel H, Hudson R. Trigeminal perception of odorant quality in congenitally anosmic subjects. Chem Senses 1997;22:447-56.

83 Doty RL, Brugger WPE, Jurs PC, et al. Intranasal trigeminal stimulation from odorous volatiles: psychometric responses from anosmic and normal humans. Physiol Behav 1978;20:175-85.

84 Keithly L, Ferris Wayne G, Cullen DM, et al. Industry research on the use and effects of levulinic acid: a case study in cigarette additives. Nicotine Tob Res 2005:7:761-71.

85 Food and Drug Administration Tobacco Products Scientific Advisory Committee. Menthol cigarettes and public health: review of the scientific evidence and recommendations. 2011. http://www.fda.gov/downloads/AdvisoryCommittees/ CommitteesMeetingMaterials/TobaccoProductsScientificAdvisoryCommittee/ UCM269697.pdf

86 Reynolds RJ. Proposed experiments for Xb. Xb basic mechanism team. 1990a. Bates No. 508949306-508949315. http://tobaccodocuments.org/product_design/ 508949306-9315.html

87 Hale R, Kroustalis C, Lin S, et al. 2307 Basic flavor investigation low tar. Research Collection, 1990. Bates number 2050878148-2050878190.

88 Ennis D. Modeling. Philip Morris, 1990. Bates number 2024847429/7627.

89 Carchman RA, Southwick MA. Chemical senses research a research and development perspective. Research Collection, 1990. Bates number 2024847429-2024847627.

90 Siddall EC, Marples NM. Better to be bimodal: the interaction of color and odor on learning and memory. Behav Ecol 2008;19:425-32.

91 Kaye $\mathrm{H}$, Mackinosh NJ, Rothschild M, et al. Odour of pyrazine potentiates an association between environmental cues and unpalatable taste. Anim Behav 1989;37:563-8.

92 R. J. Reynolds. Taste \& olfaction. RJ Reynolds, 1987. Bates number 509859364/9400.

93 Daylor FL, Spielberg HL, Swain JW. 2305 Flavor development 781200-791200 flavor development. Philip Morris, Inc, 1979. Bates number 1000379766/979.

94 Prescott J. Chemosensory learning and flavor: perception, preference, and intake. Physiol Behav 2012;107:553-9.

95 Rees VW, Kreslake JM, Wayne GF, et al. Role of cigarette sensory cues in modifying puffing topography. Drug Alcohol Depend 2012;124:1-10.

96 Lemaitre S, Lepailleur A, Bureau R, et al. Novel antagonists of serotonin-4 receptors: synthesis and biological evaluation of pyrrolothienopyrazines. Bioorg Med Chem 2009;17:2607-22.

97 Rault S, Lancelot JC, Prunier H, et al. Novel selective and partial agonists of 5-HT3 receptors. Part 1. Synthesis and biological evaluation of piperazinopyrrolothienopyrazines. J Med Chem 1996;39:2068-80.

98 Prunier H, Rault S, Lancelot JC, et al. Novel and selective partial agonists of 5-HT3 receptors. 2. Synthesis and biological evaluation of piperazinopyridopyrrolopyrazines, piperazinopyrroloquinoxalines, and piperazinopyridopyrroloquinoxalines. J Med Chem 1997;40:1808-19.

99 Wayne GF, Connolly GN. How cigarette design can affect youth initiation into smoking: Camel cigarettes 1983-93. Tob Control 2002;11(Suppl 1):132-9.

100 British American Tobacco. Reduction of tobacco smoke irritation by use of potential ameliorants. 1994. Bates number 403682358-403682377.

101 Dube LG, Willard RL, Dufour WM, et al. Mid year report 1986 (860000). Research Collection, 1986. Bates number 512829089-512829241.

102 Perfetti TA. Influence of additive and flavorants on ETS irritancy. RJ Reynolds, 1988. Bates number 508857534/7536.

103 Carpenter CM, Wayne GF, Pauly JL, et al. New cigarette brands with flavors that appea to youth: tobacco marketing strategies. Health Aff (Millwood) 2005;24:1601-10.

104 BATCo. Product technology: brand development programme. 4 October 1990. Bates number 400346673-/6788.

105 Abrams DB. Promise and peril of e-cigarettes: can disruptive technology make cigarettes obsolete? JAMA 2014;311:135-6.

106 Regan AK, Promoff G, Dube SR, et al. Electronic nicotine delivery systems. Tob Control 2013;22:19-23.

107 Centers for Disease Control and Prevention (CDC). Notes from the field. MMWR Morb Mortal Wkly Rep 2013;62:729-30.

108 Johnston LD, O'Malley PM, Miech RA, et. al. Monitoring the Future national results on adolescent drug use: Overview of key findings, 2014. Ann Arbor, Mich.: Institute for Social Research, the University of Michigan, 2015.

109 V2 Cigs. Flavor Profile v.1.2 Revised August 30, 2011. http://www.ciggutmaningen. se/download/v2-cigs-content-refillhylsor.pdf (accessed 27 Jul 2014). 